\title{
Dynamic Scan
}

National Cancer Institute

\section{Source}

National Cancer Institute. Dynamic Scan. NCI Thesaurus. Code C94890.

A scan having a number of sequential frames. 